\title{
FAM131B wt Allele
}

National Cancer Institute

\section{Source}

National Cancer Institute. FAM131B wt Allele. NCI Thesaurus. Code C106341.

Human FAM131B wild-type allele is located in the vicinity of $7 q 34$ and is approximately 9 $\mathrm{kb}$ in length. This allele, which encodes protein FAM131B, has not been characterized. 